\title{
ВІКТОР ВІКТОРОВИЧ ЛАЗАРЕВ,
}

кандидат юридичних наук, доцент,

Харківський національний університет внутрішніх справ;

https://orcid.org/0000-0001-9468-0497,

e-mail: judge2101@gmail.com;

\section{ОЛЬГА АНАТОЛІЇВНА ЖИДОВЦЕВА,}

кандидат юридичних наук,

Харківський національний університет внутрішніх справ;

e-mail:goa_1606@ukr.net

\section{ЩОДО НАУКОВОЇ ДИСКУСІЇ ПРО ЮРИДИЧНУ ПРИРОДУ ЗЛОВЖИВАННЯ ПРАВОМ}

\begin{abstract}
Визначено низку факторів, що впливають на існування явища «зловживання правом». Подано класифікацію зловживання правом залежно від відносин, яким заподіюється шкода. Розкрито сутність таких форм зловживання правом, як протиправні та карані діяння. Наведено ознаки протиправного зловживання правом. Зазначено, що зловживання правом також можна класифікувати і за галузевою ознакою (зловживання майновими правами, зловживання правом у кримінально-правовій сфері, зловживання посадовими повноваженнями у сфері державного управління).
\end{abstract}

Ключові слова: право, норма права, юридично значуща поведінка, кваліфікація, суб'єктивне право, зловживання, зловживання правом.

Оглядова стаття

\section{Постановка проблеми}

Проблема зловживання правом, попри наявність значної кількості спеціальних і монографічних досліджень, залишається однією з найбільш дискусійних у сучасній правовій доктрині, адже невизначеність цього явища у законодавстві та наявність суперечливих поглядів науковців на вказану проблематику вкрай ускладнюють виявлення шляхів попередження та уникнення таких дій у суспільстві. Між тим кількість випадків зловживання правом не зменшується, способи його вчинення стають дедалі «вишуканішими», а простір його вчинення постійно розширюється Цим зумовлюється необхідність проведення не лише галузевих, а й загальноправових досліджень відповідної проблематики [1, с. 23].

\section{Стан дослідження проблеми}

Юридично значуща поведінка постійно привертає увагу дослідників. На підтвердження зазначеної тези маємо зауважити, що це питання розглядається як на теоретичному, так і на галузевому рівні. Зокрема, О. Рогач на монографічному рівні здійснив усебічний аналіз феномену зловживання правом [2]. О. Мілетич дослідила теоретико-прикладний аспект зловживання правом [3, с. 4]. Л. Шапенко спробувала визначити сутність такої категорії, як зловживання правом, їі місце у системі правоз- начущої поведінки [4]. М. Рубащенко та Д. Бакаєв здійснили загальнотеоретичний аналіз категорії «зловживання правом», визначивши iї місце у системі юридично значущої поведінки [5; 6]. Н. Максименко дослідила особливості зловживання правом у системі трудових правовідносин [7]. Б. Карнаух розглядає зловживання правом у розрізі цивільного судочинства [8]. О. Кузнець дослідив систему цивільних і виконавчих процесуальних відносин, суб'єкти яких зловживають правами [9, с. 2]. М. Афанасьєва дослідила особливості зловживання правом під час здійснення виборчого процесу [10]. Як бачимо, вирішенню проблемних питань і визначенню сутності зловживання правом присвячено чималу кількість наукових доробок, що, на нашу думку, є позитивним напрямком, який має на меті вдосконалення вітчизняної правової системи. Водночас варто зазначити, що, незважаючи на значну кількість наукових публікацій, дослідники оминули увагою проведення класифікації зловживання правом за видами.

\section{Мета і завдання дослідження}

Meта статті - провести комплексний аналіз сутності та різновидів зловживання правом, визначити його юридичну природу.

Мета конкретизується в таких завданнях:

- визначити підстави, що можуть призвести до зловживання правом; 
- визначити підходи до здійснення класифікації зловживання правом.

\section{Наукова новизна дослідження}

Здійснено комплексне дослідження сутності такої юридичної категорії, як «зловживання правом». Висловлюється думка, що питання здійснення видового поділу тих або інших суспільних явищ $є$ досить складним. 3 огляду на це пропонується авторська пропозиція щодо здійснення класифікації видів зловживання правом.

\section{Виклад основного матеріалу}

Самостійне і безперешкодне здійснення суб'єктивних прав є одним із базових принципів, що лежить у підгрунті існування правової держави та наповнює гуманістичним змістом правовий режим взаємовідносин людини і держави. Водночас міра свободи, закладена в суб'єктивному праві, не $\epsilon$ абсолютною, вона має певні межі, вихід за які призводить до того, що йменується зловживання правом [11] До того ж відсутність у конкретних правовідносинах спеціальної норми, яка забороняє зловживати суб'єктивним правом у більшості сфер суспільних відносин, робить неможливим юридичну кваліфікацію тих чи інших дій як зловживання правом [12, с. 289].

Звертаючись до фахової літератури, ми знаходимо в ній відсутність єдиного підходу до визначення цієї категорії, тому що вона, на думку низки дослідників, більше тяжіє до конкретної ситуації. Разом із тим існує низка факторів, що впливають на існування явища зловживання правом:

- терміном «зловживання правом» слід позначати лише ті ситуації, що безпосередню стосуються права і правового регулювання; ситуації, що суперечать нормам моралі й іншим соціальним нормам, які діють у суспільстві, не є зловживанням правом;

- однією з причин створення ситуацій зі зловживанням правом виступає ставлення особи до права лише як до інструмента, придатного чи непридатного для досягнення цілей конкретною особою;

- у результаті зловживання правом страждає юридично визнана свобода, надана в однаковому обсязі об'єктивним правом того або іншого державно організованого суспільства кожному з його членів на певному етапі розвитку конкретної держави;

- складність кваліфікації зловживання правом пов'язується саме з тим, що будь-яка ситуація зі зловживанням правом завжди формально відповідає букві закону, а власне термін «зловживання правом» передає основну суть такого процесу використання особою можливостей, які містяться у правовій нормі, що із зовнішнього або техніко-юридичного боку виглядає так само, як правомірний вчинок («легальна видимість»);

- результат втілення тієї чи іншої «ситуації, що має контури зловживання правом» у життя не залежить від способу здійснення ситуації з «легальною видимістю»;

- незважаючи на те, що в разі зловживання правом не відбувається формального порушення положень конкретних нормативноправових актів, будь-яке зловживання правом це завжди протиправна дія, бездіяльність або рішення, оскільки в результаті здійснення ситуації зі «зловживанням правом» завжди порушується принцип недопустимості зловживання правом, який встановлює, що здійснення прав і свобод людини і громадянина не повинно порушувати права і свободи інших осіб;

- присутність у вітчизняному законодавстві однойменних категорій права (наприклад, зловживання процесуальними правами) пояснюється процесом трансформації (який відбувається постійно) правової категорії «зловживання правом» у нормативно-правову систему країни [13, с. 19-20].

Залежно від того, яким суспільним відносинам заподіюється шкода в процесі здійснення права в суперечності з його призначенням, зловживання правом можна класифікувати, поділивши на правомірні (легальні) та протиправні. У підгрунтя цього розподілу може бути покладена як правова природа суспільних відносин, тобто той факт, знаходиться воно у сфері правового регулювання чи ні, так і юридичний критерій оцінювання шкоди. Якщо заподіяння шкоди суспільним відносинам протиправне і каране, то перед нами протиправне зловживання правом. Якщо ні - умовно кажучи, юридично нейтральне [14, с. 86-87].

Юридично нейтральне зловживання правом заподіює шкоду не охоронюваним законом відносинам, тому такі зловживання залежно від конкретних обставин можна розглядати як аморальні або недоцільні [14, с. 87].

Суб'єкт діє аморально, якщо, здійснюючи суб'єктивне право, він не співвідносить свою поведінку 3 конкретно-історичними уявленнями про добро і зло, хороше і погане, із загальнолюдськими цінностями, соціально визнаними нормами, що регулюють ставлення людей одне до одного, до родини, суспільства, держави. Важливо підкреслити, що, добираючись до поставленої мети, суб'єкт права, суворо кажучи, використовує зовсім не ті юридичні 
засоби (одружується або виходить заміж), що для цього необхідні. Причому право не забороняє йому так вчиняти [14, с. 87].

Суб'єкт вчиняє недоцільно, якщо зазначену в законі мету раціональніше досягти шляхом використання інших правових засобів $[14$, c. 87-88].

Імітуючи правомірну поведінку, а, по суті, зловживаючи правом, суб'єкт може безкарно обмежувати (ускладнювати) можливість реалізації прав і законних інтересів інших осіб.

Таким чином, аморальне або недоцільне здійснення суб'єктом свого права у виді використання правових приписів, якщо в результаті цього була заподіяна шкода іншим учасникам суспільних відносин, необхідно розглядати як легальне зловживання правом. Суб'єкт у даному випадку не чинить правопорушень і не підлягає юридичній відповідальності [14, с. 88].

Іншою формою зловживань правом $\epsilon$ протиправні і карані діяння. До протиправних належать тільки такі зловживання, які скоюються суб'єктами, що реалізують свої права, свободи і владні повноваження. Звичайне порушення правової заборони невправомоченим суб'єктом не можна розглядати як зловживання. Дійсно, вбивця або грабіжник, здійснюючи об'єктивну сторону свого діяння, аж ніяк не реалізують тим самим своїх суб'єктивних прав. Водночас оратор, виступаючи на мітингу з образами на адресу політичного супротивника, учиняє злочин за допомогою зловживання свободою слова [14, с. 88].

3 об'єктивної сторони зловживання правом відрізняється від правопорушення тим, що суб'єкт у даному випадку вчиняє протиправне діяння за допомогою реалізації свого суб'єктивного права (правомочності), і первісна стадія його діяння перебуває у рамках закону. Причому це стосується як громадян, так і посадових осіб [14, с. 89].

О. Малиновський зазначає, що в юридичній науці сформульовано думку, згідно з якою визнання зловживання правом як правопорушення грунтується на тезі, що критерієм оцінки правомірності (неправомірності) поведінки суб'єктів при відсутності конкретної норми можуть служити норми, що закріплюють загальні принципи [12, с. 289].

Протиправне зловживання характеризується наступними ознаками:

1) суб'єкт, реалізуючи надане йому суб'єктивне право, порушує приписи діючого законодавства;

2) реалізацією суб'єктивного права в протиріччі з його призначенням заподіюється шкода охоронюваним законом відносинам;
3) наявний причинно-наслідковий зв'язок між протиправним діянням і негативними наслідками [14, с. 89].

Дуже часто зловживання правом $є$ способом здійснення протиправних діянь. Наприклад, журналіст, зловживаючи свободою масової інформації, може скоїти такі злочини, як наклеп, образа, розпалювання національної, расової або релігійної ворожнечі.

Зловживання правом також можна класифікувати і за галузевою ознакою (зловживання майновими правами, зловживання правом у кримінально-правовій сфері, зловживання посадовими повноваженнями у сфері державного управління) [14, с. 90].

Кожна з форм зловживання правом може бути поділена на види та підвиди залежно від засобу зловживання, тобто від виду суб'єктивного права або правомочності як елементів правоздатності, якими зловживають $[15$, c. 67$]$.

За цим критерієм кожна з форм зловживання правом може бути поділена на такі дві групи видів зловживання правом:

1) зловживання правомочністю як елементом цивільної правоздатності, зокрема: а) використання цивільних прав з метою обмеження конкуренції та зловживання домінуючим становищем на ринку; б) зловживання «переддоговірними» правами (при підготовці та укладенні договорів);

2) зловживання окремими видами суб'єктивних цивільних прав: а) корпоративними правами; б) речовими правами; в) зобов'язальними правами; г) особистими немайновими правами; г') правами інтелектуальної власності; д) батьківськими правами та правами осіб, які замінюють батьків.

У підгрунтя поділу зловживань правом на види може бути покладена як правова природа суспільних відносин, тобто той факт, перебуває воно у сфері правового регулювання чи ні, так і юридичний критерій оцінювання шкоди. Тому залежно від того, яким суспільним відносинам заподіюється шкода в процесі здійснення права всупереч його призначенню, зловживання правом можна класифікувати, поділивши на зовні правомірні, але такі, що суперечать «духу права», і протиправні (ті, що суперечать букві закону). Залежно від характеру заподіяної шкоди протиправні зловживання правом необхідно поділяти на злочини й інші правопорушення [15, с. 67].

\section{Висновки}

Підбиваючи підсумки дослідження, маємо зазначити таке: 
- зважаючи на особливості сучасного законодавства, зокрема наявність у ньому колізійних норм, прогалин і суперечностей, зауважимо, що ці фактори можуть призвести до можливостей зловживання правом; переважно це притаманно випадкам, коли суб'єктивному праву кореспондується обов'язок, за невиконання якого на рівні законодавства не передбачено юридичну відповідальність;

- питання здійснення видового поділу тих або інших суспільних явищ $є$ достатньо складним.

Особливо це стосується тих випадків, коли йдеться про здійснення класифікації складних та різноманітних правових явищ, до яких слід віднести і зловживання правом. Так, зловживання правом можна класифікувати за різними підставами, водночас варто розуміти, що будь-яка класифікація відображатиме лише частину особливостей досліджуваного явища. Саме тому необхідно створювати різні класифікації, які у сукупності забезпечать розуміння досліджуваного явища. У першу чергу, ми можемо здійснити таку класифікацію досліджуваного явища:

- за суб'єктивною стороною: умисні й неумисні;

- за галузевою належністю;

- за суб'єктом: зловживання фізичних i юридичних осіб;

- за часом дії: закінчені й ті, що тривають;

- залежно від характеру заподіяної шкоди: злочини й інші правопорушення.

\section{Список бібліографічних посилань}

1. Рєзнікова В.В. Зловживання правом: поняття та ознаки. Університетські наукові записки. 2013. № 1. C. 23-35. URL: https://law.lnu.edu.ua/wp-content/uploads/2019/09/Literatura-9.pdf (дата звернення: 11.02.2021).

2. Рогач О. Я. Зловживання правом: теоретико-правове дослідження. Ужгород : Ліра, 2011. 368 с.

3. Мілетич О. О. Зловживання правом: теоретико-прикладний аспект : автореф. дис. ... канд. юрид. наук : 12.00.01. Київ, 2015. 21 с.

4. Шапенко Л. О., Степанківська Н. А. Зловживання правом як загроза стабільним суспільним відносинам. Юридичний науковий електронний журнал. 2014. № 6. C. 29-32. URL: http://lsej.org.ua/ 6_2014/7.pdf (дата звернення: 11.02.2021).

5. Рубащенко М. Зловживання правом як загальноправова категорія: допустимість, сутність, кваліфікація.Юридичний журнал. 2010. № 4. С. 110-119. URL: http://dspace.nlu.edu.ua/bitstream/ 123456789/14477/1/Rubashenko_110-119.pdf (дата звернення: 11.02.2021).

6. Бакаєв Д. С. Концепція зловживання правом у правовій доктрині: порівняльно-правовий аспект. Часопис Київського університету права. 2013. № 1. С. 33-36.

7. Максименко Н. Зловживання правом сторонами трудових правовідносин. Підприємнищтво, господарство і право. 2018. № 10. С. 89-93.

8. Карнаух Б. Зловживання правом та його правові наслідки. Підприємництво, господарство $i$ право. 2020. № 9. С. 31-36.

9. Кузнець О. М. Суб'єкти зловживання правами у цивільному та виконавчому процесі : автореф. дис. ... канд. юрид. наук : 12.00.03. Київ, 2016. 23 с.

10. Афанасьєва М. В. Зловживання правом у виборчому процесі. Наукові праці Національного університету «Одеська юридична академія». 2011. T. 10. C. 153-163. URL: http://naukovipraci.nuoua.od.ua/ arhiv/tom10/16.pdf (дата звернення: 11.02.2021).

11. Юхимюк О. М. Загальнотеоретична характеристика зловживання суб'єктивним правом // Актуальні питання реформування правової системи України : зб. наук. пр. за матеріалами VII Міжнар. наук.-практ. конф. (м. Луцьк, 4-5 черв. 2010 р.) / Волинськ. нац. ун-т ім. Лесі Українки ; редкол.: I. Я. Коцан та ін. Луцьк : Волин. обл. друк., 2010. С. 115-118. URL: https://evnuir.vnu.edu.ua/bitstream/ 123456789/2355/1/konf_akt_pytan2010.pdf (дата звернення: 11.02.2021).

12. Малиновский А. А. Злоупотребление субъективным правом (теоретико-правовое исследование). М. : Юрлитинформ, 2007. 352 с.

13. Калюжний Р. А., Андрущенко І. Г. Зловживання правом: сутність та шляхи протидії. Бюлетень Міністерства юстиції України. 2006. № 8 (58). C. 16-22. URL: https://er.nau.edu.ua/bitstream/NAU/ 26483/1/ЗЛОВЖИВАННЯ\%20ПРАВОМ.pdf (дата звернення: 11.02.2021).

14. Хміль М. М. Принцип неприпустимості зловживання правом (теоретико-правові аспекти) : дис. ... канд. юрид. наук : 12.00.01. Харків, 2005. 199 с.

15. Осадчук С., Осадчук М. Форми зловживання цивільним правом. Актуальні проблеми правознавства. 2016. Вип. 4. С. 68-77. URL: http://dspace.wunu.edu.ua/bitstream/316497/18279/1/ Осадчук\%20C..pdf (дата звернення: 11.02.2021). 


\section{ЛАЗАРЕВ В. В., ЖИДОВЦЕВА О. А. ОТНОСИТЕЛЬНО НАУЧНОЙ ДИСКУССИИ О ЮРИДИЧЕСКОЙ ПРИРОДЕ ЗЛОУПОТРЕБЛЕНИЯ ПРАВОМ}

Определен ряд факторов, оказывающих влияние на существование явления «злоупотребление правом». Приведена видовая классификация злоупотребления правом в зависимости от отношений, которым причиняется вред. Раскрыта сущность таких форм злоупотребления правом, как противоправные и наказуемые деяния. Приведены признаки противоправного злоупотребления правом. Отмечено, что злоупотребление правом можно классифицировать и по отраслевому признаку (злоупотребление имущественными правами, злоупотребление правом в уголовно-правовой сфере, злоупотребления должностными полномочиями в сфере государственного управления)

Ключевые слова: право, норма права, юридически значимое поведение, квалификация, субъективное право, злоупотребления, злоупотребление правом.

\section{LAZARIEV V. V., ZHYDOVTSEVA O. A. REGARDING SCIENTIFIC DISCUSSION ON LEGAL NATURE OF THE LAW ABUSE}

The authors have analyzed the facts inherent in the equitable right that can lead to abuse of law. It has been emphasized that the legal literature has no single approach to the definition of the term of "law abuse". However, there is a number of factors that influence the existence of such a specific phenomenon as "law abuse".

Attention has been paid to the species classification of law abuse. It has been noted that depending on what public relations are harmed in the process of exercising the right contrary to its purpose, law abuse can be divided into lawful (legal) and illegal. The general characteristic of lawful (legal) and illegal abuse of law has been presented; their features have been named. It has been emphasized that abuse of law can also be classified by the branch (abuse of property rights, abuse of rights in criminal law, white collar crime within public administration sphere). Attention has been paid to the fact that each of the forms of law abuse can be divided into types and subspecies depending on the means of abuse, i.e. depending on the type of equitable right or jurisdiction as elements of legal capacity, which are abused.

As a result, it has been concluded that the peculiarities of modern legislation, in particular the presence of conflicting rules, gaps and contradictions, can lead to abuse of law. This is mainly the case when the equitable right corresponds to an obligation for non-fulfillment of which there is no legal liability at the level of legislation.

As a result, it has been noted that law abuse can be currently classified on various grounds, but it should be understood that any classification will reflect only part of the features of the studied phenomenon.

Key words: law, law norm, legally significant behavior, qualification, equitable right, abuse, law abuse. 